\begin{abstract}
Iranica
Abstracta Iranica Revue bibliographique pour le domaine irano-aryen

Volume 37-38-39 | 2018

Comptes rendus des publications de 2014-2016
\end{abstract}

\title{
Josef Wiesehöfer. „Das ,Paradies‘. Persische Parkkultur als Zeugnis herrscherlicher Legitimation und Repräsentation"
}

\section{Astrid Nunn}

\section{(2) OpenEdition}

Journals

Édition électronique

URL : http://journals.openedition.org/abstractairanica/46185

DOI : 10.4000/abstractairanica.46185

ISBN : 1961-960X

ISSN : 1961-960X

Éditeur :

CNRS (UMR 7528 Mondes iraniens et indiens), Éditions de l'IFRI

\section{Référence électronique}

Astrid Nunn, « Josef Wiesehöfer. „Das ,Paradies'. Persische Parkkultur als Zeugnis herrscherlicher Legitimation und Repräsentation" », Abstracta Iranica [En ligne], Volume 37-38-39 | 2018, document 72, mis en ligne le 30 décembre 2018, consulté le 26 septembre 2020. URL : http://

journals.openedition.org/abstractairanica/46185; DOI : https://doi.org/10.4000/abstractairanica 46185

Ce document a été généré automatiquement le 26 septembre 2020.

Tous droits réservés 


\title{
Josef Wiesehöfer. „Das ,Paradies‘. Persische Parkkultur als Zeugnis herrscherlicher Legitimation und Repräsentation“
}

\author{
Astrid Nunn
}

\section{RÉFÉRENCE}

Josef Wiesehöfer. „Das ,Paradies'. Persische Parkkultur als Zeugnis herrscherlicher Legitimation und Repräsentation" in Joachim Ganzert, Inge Nielsen (Hg.).

Herrschaftsverhältnisse und Herrschaftslegitimation. Bau- und Gartenkultur als historische quellengattung hinsichtlich Manifestation und Legitimation von Herrschaft / Power

Relationships and Legitimation of Power. Bau- und Gartenkultur as a Historical Source of the Manifestation and Legitimation of Rule and Power. Symposium 22-24 Oktober 2014. Berlin/ Münster: LIT Verlag, 2016, p. 49-64 (Hephaistos. Kritische Zeitschrift zu Theorie und Praxis der Archäologie und angrenzender Gebiete)

1 L'eau, en Iran comme dans tout le Proche-Orient, possède une valeur concrète inestimable qui se reflète dans son importance symbolique. Source de toute vie possible, ceci explique la nouvelle interprétation grecque du mot perse "paradis". L'A. donne des exemples de jardins en Mésopotamie et examine l'approvisionnement en eau. le Grand Roi, responsable de sa gestion, avait entre autres fonctions d'assurer des ressources suffisantes pour la population et l'agriculture. Il s'est entouré lui aussi de splendides parcs et de jardins irrigués, pour lesquels des techniques hydrauliques furent développés. Un jardin florissant, empli de plantes et d'animaux utiles, reflétait la faveur des dieux. La bonne administration de l'eau était une preuve des capacités du Roi et a même légitimé son pouvoir au cours des temps. C'est ainsi que les images du roi 
chasseur dans un parc et l'image du "bon jardinier" sont devenues des images identitaires de l'aristocratie en Iran.

\section{AUTEURS}

\section{ASTRID NUNN}

Université de Munich 